\title{
Modelowanie spawalniczego źródła ciepła w procesie spawania hybrydowego
}

\section{Modeling of welding heat source in the hybrid welding process}

\section{Streszczenie}

Bardzo szybki rozwój technik komputerowych umożliwia obecnie analizę naprężeń spawalniczych dla większości procesów spawania. Dość dobrze opisane są rodzaje spawalniczych modeli źródeł ciepła, które są niezbędne dla wyznaczenia pola temperatury podczas spawania. Występujący przy spawaniu gradient temperatury jest jedną z głównych przyczyn powstawania naprężeń spawalniczych, które mogą znacząco wpływać na trwałość eksploatacyjną złączy spawanych. Stąd, modelowanie pola temperatury przy spawaniu jest jednym z niezbędnych elementów służących oszacowaniu odkształceń i naprężeń w konstrukcjach spawanych.

Procesy spawania hybrydowego należą do nowej grupy odmian spawania łączących ze sobą najczęściej dwie klasyczne metody spawania jak np. spawanie laserowe i spawanie GMA czy spawanie plazmowe i spawanie GMA. Modelowanie naprężeń spawalniczych w tego typu odmianach spawania wymaga zdefiniowania nowego rodzaju modelu źródła ciepła łączącego skoncentrowany strumień energii z klasycznym źródełem ciepła, jakie występuje w łuku elektrycznym.

W pracy przedstawiono próbę opisu modelu spawalniczego źródła ciepła dla spawania hybrydowego w odmianie łuk plazmowy (spawanie plazmowe) + łuk klasyczny (spawanie GMA). W tym celu zbudowano przestrzenny model numeryczny (MES) dwóch płyt stalowych spawanych doczołowo metodą hybrydową (plazma+GMA). Zamieszczono wyniki symulacji numerycznej pola temperatury powstającego przy spawaniu hybrydowym dla zaproponowanego hybrydowego modelu spawalniczego źródła ciepła. Przeprowadzono dyskusję wyników w odniesieniu do kształtu spoiny hybrydowej uzyskanej dla identycznych parametrów procesu spawania hybrydowego.

Słowa kluczowe: spawanie hybrydowe; plazma+GMA; modelowanie numeryczne; pole temperatury

\begin{abstract}
The rapid development of computer technology now allows for analysis of welding stresses for most welding processes. The types of welding heat sources that are necessary to determine the temperature field during welding are well described. The temperature gradient that occurs during welding is one of the major causes of welding residual stresses that can significantly affect the service life of welded joints. Hence, modeling the temperature field during welding is one of the necessary elements for estimating deformation and stresses in welded constructions.

Hybrid welding processes belong to a new group of welding variants that combine most commonly two conventional welding methods, such as laser welding and GMA welding or plasma welding and GMA welding. Modeling of welding residual stresses in this type of welding requires the definition of a new type of heat source model combining a concentrated stream of energy with the classical heat sources present in the welding arc.

The paper presents an attempt to describe the model of heat source used in hybrid welding combining the plasma arc (plasma welding) and electric arc (GMA welding). For this purpose, a 3D numerical model (FEM) of two hybrid welded (plasma+GMA) steel plates was used. The results of the numerical simulations of the temperature field generated by hybrid welding for the proposed hybrid heat source model are presented. Discussion of the results with respect to the shape of the hybrid weld obtained for identical parameters of the hybrid welding process was discussed.
\end{abstract}

Keywords: laser; laser welding; automotive industry; laser beam

\section{Wstęp}

Pole temperatury w procesach spajania odgrywa kluczową rolę i jest przedmiotem wielu badań i analiz głównie poprzez wykorzystanie nowoczesnych narzędzi modelowania numerycznego $[1 \div 4]$. Rozkład temperatury ma wpływ na szereg czynników, wpływających na jakość otrzymanego złącza, do których zaliczyć należy strukturę spoiny i obszaru strefy wpływu ciepła, jej wielkość, czy też powstające deformacje i spawalnicze naprężenia własne $[5,6]$.

Mgr inż. Damian Rochalski; dr hab. inż. Dariusz Golański, prof. PW; dr hab. inż. Tomasz Chmielewski, prof. PW - Politechnika Warszawska.

Autor korespondencyjny/Corresponding author: dgol@wip.pw.edu.pl 
Dlatego też znajomość rozkładu pola temperatury w trakcie procesu spawania jest niezwykle ważna, bowiem niesie ze sobą kluczowe informacje na temat zjawisk zachodzących w materiale spawanym. W zależności od zastosowanej metody spawania czy nawet różnych parametrów spawania pole to może przybierać różny kształt. Nie jest więc możliwe wykorzystanie jednego wspólnego dla wszystkich procesów spawania modelu źródła ciepła, który będzie właściwy do analizy pola temperatury dla różnych procesów spawania. Dlatego też podstawowym elementem analizy numerycznej procesów spawania jest właściwy dobór odpowiedniego modelu spawalniczego źródła ciepła. W szeroko obecnie stosowanych procesach spawania łukowego (MIG/MAG, TIG, SAW) powszechnie stosuje się $\mathrm{W}$ modelowaniu pola temperatury tzw. podwójnie elipsoidalne źródło ciepła opisane modelem Goldaka [7], który stanowił znaczące rozszerzenie szeregu wcześniejszych uproszczonych modeli opisujących oddziaływanie źródeł ciepła w procesach spawania [8]. Model Goldaka opisuje oddziaływanie ciepła na powierzchni spawanych materiałów oraz w ich głąb za pomocą dwóch elipsoid o określonych parametrach zależnych od procesu spawania. W przypadku procesów spawania skoncentrowaną wiązką energii jak np. spawanie laserowe czy spawanie wiązką elektronów, gdzie ma miejsce powstawanie kanału parowego, model Goldaka nie sprawdza się. Stosuje się tutaj modele źródeł ciepła najczęściej w kształcie walca lub prostopadłościanu o niedużym przekroju podstawy [9] albo odwróconego ściętego stożka [10]. Modele te lepiej oddają naturę skoncentrowanego źródła ciepła o mniej więcej stałym przekroju na całej grubości materiału spawanego. W stosowanych obecnie komercyjnych programach komputerowych służących symulacji pola temperatury przy spawaniu łukowym (Sysweld, Simufact Welding, Transweld) jak i metodami wiązkowymi wspomniane modele źródeł ciepła są zazwyczaj powszechnie zaimplementowane i łatwo stosowane.

Postępujący rozwój procesów spawania doprowadził do powstania nowych odmian tzw. spawania hybrydowego łączącego w sobie zazwyczaj dwie metody spawania: spawanie łukowe ze spawaniem skoncentrowaną wiązką energii np. lasera. W takiej odmianie procesu spawania pole temperatury powstaje w wyniku równoczesnego oddziaływania łuku elektrycznego i np. skoncentrowanej wiązki lasera. Przykładem spawania hybrydowego jest najczęściej połączenie metody spawania laserowego z metodą MIG/MAG [11] czy też z metodą TIG [12]. Istnieją również odmiany spawania hybrydowego oparte na połączeniu skoncentrowanego łuku plazmowego z metodą MAG (plazma+GMA) [13]. Modelowanie pola temperatury $w$ procesach spawania hybrydowego wymaga więc odpowiedniego połączenia dwóch różnych modeli źródeł ciepła stosowanych osobno w klasycznych procesach spawania. Tego typu podejście jest obecnie tematem szeregu badań, mających na celu dobór najbardziej odpowiedniej kombinacji spawalniczych źródeł ciepła, które będą precyzyjnie odzwierciedlać charakter pola temperatury, jaki powstaje podczas spawania hybrydowego. Dane literaturowe wskazują, że obecnie główne badania skupiają się na opracowaniu modeli źródeł ciepła dla spawania hybrydowego opartego przede wszystkim na spawaniu laserowym w połączeniu ze spawaniem łukowym GMA lub spawaniem TIG.

W niniejszej pracy skupiono się na niezbyt często jeszcze stosowanej metodzie spawania hybrydowego plazma+GMA. Praktycznie brak jest przykładów literaturowych modelowania pola temperatury dla tej odmiany spawania hybrydowego, która posiada szereg zalet w stosunku do innych metod spawania. W pracy zaprezentowano wstępną próbę opracowania spawalniczego źródła ciepła w hybrydowej odmianie spawania plazma+GMA zastosowanej do spawania blach ze stali S700MC. Celem pracy była próba zbudowania przestrzennego modelu hybrydowego źródła ciepła obejmującego część plazmy, która powoduje głębokie wtopienie w materiał spawany oraz łuk elektryczny podążający za plazmą w celu wypełnienia spoiny. Przeprowadzone modelowanie numeryczne pola temperatury z wykorzystaniem modelu hybrydowego źródła ciepła odniesione zostało do kształtu spoiny wykonanej metodą hybrydową plazma+GMA dla tych samych parametrów spawania w celu wstępnej weryfikacji opracowanego modelu.

\section{Spawanie hybrydowe plazma+GMA}

Spawanie hybrydowe plazma+GMA łączy w sobie zalety obu rozwiązań zastosowanych w tej metodzie. Z jednej strony źródło ciepła w postaci wysokoenergetycznej plazmy zapewnia głębokie wtopienie, a klasyczne źródło ciepła GMA wypełnia rowek spawalniczy. Takie połączenie znacznie podnosi wydajność spawania, zmniejsza udział stopiwa w spoinie, a co najważniejsze zmniejsza konieczność precyzyjnego przygotowania brzegów do procesu spawania, co w warunkach przemysłowych często staje się niemożliwe. Spawanie hybrydowe z zastosowaniem plazmy jest z punktu widzenia inwestycyjnego oraz eksploatacyjnego znacznie tańszym rozwiązaniem w porównaniu do tego, w którym używany jest laser. Ta innowatorska metoda spawania plazma+GMA opiera się na zastosowaniu specjalnej kurtyny magnetycznej, dzięki której prąd zarówno łuku plazmowego, jak i łuku pochodzącego od GMA przepływa przez materiał spawany. W innym przypadku nastąpiłoby jego wzajemne znoszenie ze względu na przeciwną polaryzację [13].

Złącze spawane metodą hybrydową plazma+GMA zostało wykonane $z$ dwóch blach ze stali S700MC o grubości $10 \mathrm{~mm}$ i wymiarach $350 \mathrm{~mm}$ na $150 \mathrm{~mm}$. Proces spawania przebiegał w pozycji podolnej PA, a płyty próbne zostały przygotowane do spawania zgodnie $z$ rysunkiem 1 . Zastosowany proces plazma+GMA pozwala na wykonanie niewielkiego ukosowania, które w tym przypadku wynosi $30^{\circ} \mathrm{z}$ progiem $6 \mathrm{~mm}$. Zdecydowano się na zachowanie odstępu między łączonymi blachami na poziomie 1,6 $\mathrm{mm}$.

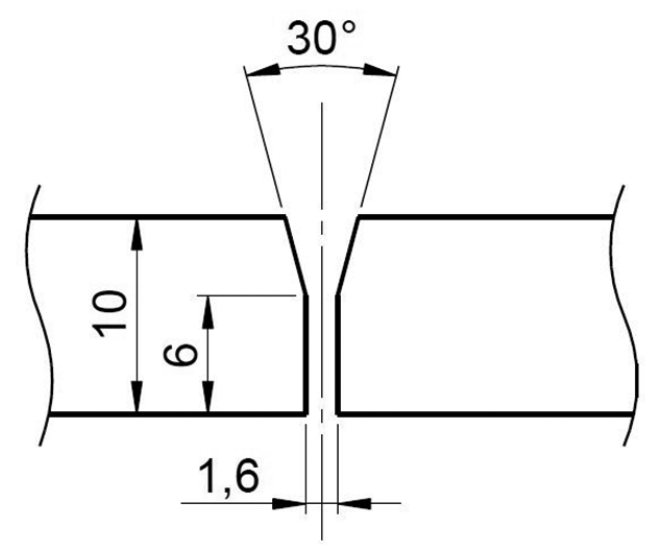

Rys. 1. Przygotowanie brzegów do procesu spawania plazma+GMA Fig. 1. The preparation of edges for the hybrid plasma+GMA welding

W procesie spawania hybrydowego wykorzystano parametry zamieszczone w tablicy I. Zastosowane parametry pozwoliły uzyskać spoinę czołową o pełnym przetopie przy bardzo dużej prędkości spawania $100 \mathrm{~cm} / \mathrm{min}$, co pokazuje duży potencjał tej metody.

Na rysunku 2 została przedstawiona mikrostruktura wykonanego złącza w przekroju poprzecznym. Możliwa do zaobserwowania linia wtopienia ukazuje kształt spoiny w postaci „kielicha”, co jest charakterystyczne dla metod hybrydowych. 
Tablica I. Parametry procesu łączenia

Table I. Joining process parameters

\begin{tabular}{|c|c|c|c|c|c|}
\hline $\begin{array}{c}\text { Prąd } \\
\text { plazmowy } \\
\text { [A] }\end{array}$ & $\begin{array}{c}\text { Napięcie } \\
\text { tuku pla- } \\
\text { zmowego } \\
\text { [V] }\end{array}$ & $\begin{array}{c}\text { Prąd } \\
\text { GMA } \\
\text { [A] }\end{array}$ & $\begin{array}{c}\text { Napię- } \\
\text { cie tuku } \\
\text { GMA } \\
{[\mathrm{V}]}\end{array}$ & $\begin{array}{c}\text { Prędkość } \\
\text { spawania } \\
\text { [cm/min] }\end{array}$ & $\begin{array}{c}\text { Energia } \\
\text { liniowa } \\
{[\mathrm{kJ} / \mathrm{cm}]}\end{array}$ \\
\hline 350 & 30 & 369 & 29,3 & 100 & 9 \\
\hline
\end{tabular}

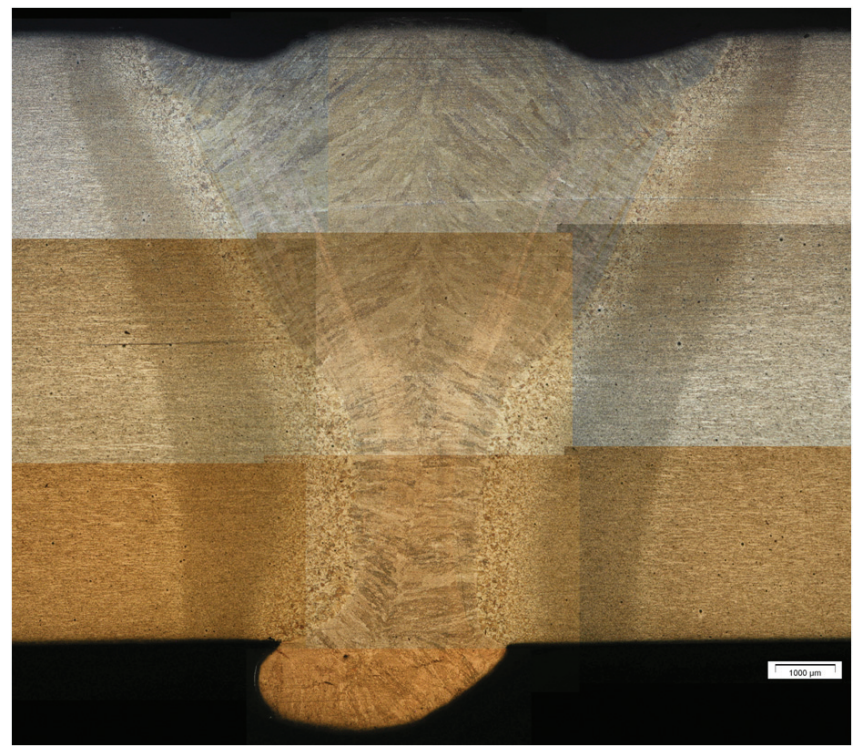

Rys. 2. Mikrostruktura złącza spawanego metodą hybrydową plazma+GMA

Fig. 2. The microstructure of the plasma+GMA hybrid welded joint

Górna część przekroju spoiny przypomina trójkąt i jest podobna do spoin wykonywanych tradycyjną metodą GMA przy zachowaniu odpowiedniego kąta ukosowania. Zaś w jej dolnej części linie wtopienia po obu stronach są niemalże równoległe do siebie tworząc kształt prostokąta. Niezgodność w postaci niewielkiego wklęśnięcia w licu spoiny obniża wytrzymałość w danym przekroju złącza, jednak nie dyskwalifikuje tego złącza, wykonanego do celów porównawczych.

\section{Model źródła ciepła dla spawania hybrydowego plazma+GMA}

$\mathrm{Na}$ podstawie uzyskanych wyników doświadczalnych ze złączy spawanych hybrydowo podjęto próbę budowy modelu hybrydowego źródła ciepła plazma+GMA, które w procesie modelowania pola temperatury przy spawaniu, byłoby w stanie możliwie najlepiej odzwierciedlić kształt przekroju poprzecznego wykonanej spoiny. Modelowanie numeryczne pola temperatury podczas spawania hybrydowego przeprowadzono za pomocą programu do analizy zagadnień cieplnych i mechanicznych LUSAS FEA v.14.7 opartego na metodzie elementów skończonych (MES). Ze względu na występujące ograniczenia programu MES ogólnego przeznaczenia model hybrydowego źródła ciepła zbudowano w oparciu o połączenie dwóch modeli spawalniczych źródeł ciepła: powszechnie stosowanym w metodach spawania łukowego modelu Goldaka oraz modelem prostopadłościennym przybliżającym skoncentrowane spawalnicze źródło ciepła, jakim jest np. laser, wiązka elektronowa czy też strumień plazmy. Model Goldaka, tak zwany podwójnie elipsoidalny, ma szerokie zastosowanie, gdyż sterując odpowiednimi parametrami opisującymi półosie elips możemy $\mathrm{w}$ bardzo szerokim zakresie wpływać na jego kształt. Niesie to za sobą również niebezpieczeństwo nieodpowiedniego dobrania tych parametrów, co w konsekwencji może doprowadzić do błędnych wyników. Dla przyjętej analizy pola temperatury przy spawaniu hybrydowym parametry opisujące elipsy (rys. 3) w modelu Goldaka dobrano na podstawie uzyskanego widoku złącza spawanego otrzymanego w wyniku badań doświadczalnych i wynoszą one:

a - szerokość penetracji źródła ciepła: $5 \mathrm{~mm}$

b - wielkość penetracji źródła ciepła w głąb materiału: $6 \mathrm{~mm}$ $\mathrm{C}_{\mathrm{f}}-$ przednia głębokość penetracji wzdłuż osi spoiny: $5 \mathrm{~mm}$ $\mathrm{C}_{\mathrm{r}}$ - tylna głębokość penetracji wzdłuż osi spoiny: $10 \mathrm{~mm}$.

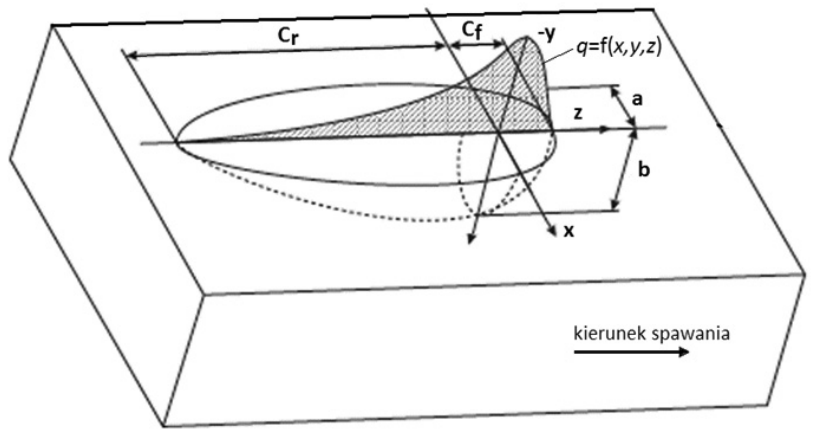

Rys. 3. Model podwójnie elipsoidalny Goldaka spawalniczego źródła ciepła [8]

Fig. 3. Double - ellipsoid Goldak model of a welding heat source [8]

Całkowita moc źródła ciepła $\mathrm{Q}_{\mathrm{G}}$ dla modelu Goldaka została obliczona na podstawie przyjętych danych w badaniach doświadczalnych:

$$
\mathrm{Q}_{\mathrm{G}}=\eta \cdot \mathrm{U}_{\mathrm{M}} \cdot \mathrm{I}_{\mathrm{M}}
$$

gdzie:

- sprawność procesu GMA: $\eta=0,8$;

- napięcie łuku GMA: $U_{M}=29,3[\mathrm{~V}]$;

- natężenie prądu GMA: $I_{M}=369[A]$;

stąd: $Q_{G}=0,8 \cdot 29,3 \cdot 369=8650[W]$.

Zastosowany model prostopadłościenny dla źródła opisującego strumień plazmy charakteryzuje się w odróżnieniu od modelu Goldaka jednorodnym rozkładem. Ma on kształt prostopadłościanu o wymiarach $2 \times 2 \times 10 \mathrm{~mm}$, a więc oddziałuje na całej grubości spawanych płyt. Całkowita moc źródła ciepła $Q_{P}$ została również obliczona na podstawie przyjętych danych:

$$
Q_{P}=\eta \cdot U_{P} \cdot I_{P}
$$

gdzie:

- sprawność plazmy: $\eta=0,6$;

- napięcie łuku plazmowego: $U_{P}=30[\mathrm{~V}]$;

- natężenie prądu plazmowego: $I_{P}=350[\mathrm{~A}]$;

stąd: $Q_{P}=0,6 \cdot 30 \cdot 350=6300[W]$.

Głównym celem przeprowadzonej analizy numerycznej było uzyskanie zbliżonego rozkładu pola temperatury na przekroju złącza spawanego, porównując go do obrazu spoiny otrzymanego w wyniku próby doświadczalnej spawania. Tego typu porównanie jest często stosowane przez wielu badaczy i uznawane za wstępną weryfikację tworzonych nowych modeli spawalniczych źródeł ciepła. Przy takim podejściu stosuje się pewne przybliżenie, zgodnie z którym pola temperatury $w$ analizowanym przekroju złącza spawanego będą miały podobny rozkład, jeśli uzyskane obrazy kształtów przekroju poprzecznego spoiny będą do siebie zbliżone. 


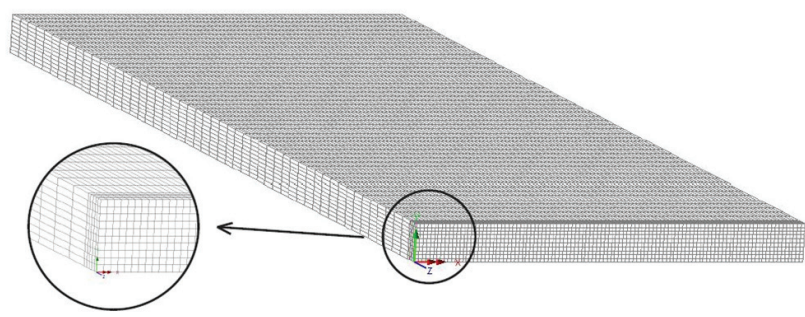

Rys. 4. Model z siatką elementów skończonych płyt spawanych hybrydowo plazma+GMA

Fig. 4. The geometry and FE mesh of steel plates used in hybrid plasma+GMA welding

Dla celu analizy numerycznej pola temperatury przy spawaniu hybrydowym plazma+GMA zbudowano przestrzenny (3D) model geometryczny spawanych płyt stalowych, na który nałożono siatkę składającą się z 57750 prostopadłościennych elementów skończonych typu HF8 (rys. 4). Siatka zagęszczona została w obszarze styku dwóch blach, tam gdzie występuję przemieszczające się spawalnicze źródło ciepła.

Z uwagi na symetrię osiową geometrii złącza spawanych płyt zbudowany model MES obejmuje tylko jedną płytę oraz połowę geometrii spawalniczego źródła ciepła opisującego model hybrydowy. Takie działanie zmniejsza znacząco czas potrzebny zarówno na przygotowanie modelu, jak i na prze-prowadzenie obliczeń w ramach symulacji komputerowej pola temperatury przy przemieszczającym się źródle ciepła.

Warunki określające wymianę ciepła zachodzącą pomiędzy źródłem ciepła a materiałem spawanym opisane są na drodze przewodnictwa cieplnego przy założonej obliczonej mocy cieplnej spawalniczego hybrydowego źródła ciepła. Wymiana ciepła na drodze konwekcji oraz promieniowania została uwzględniona we współczynnikach sprawności procesu. Warunki brzegowe wymiany ciepła pomiędzy materiałem spawanym a otoczeniem określono za pomocą konwekcji swobodnej, dla której wartość współczynnika konwekcji ustalono na poziomie $a_{k}=10 \mathrm{~W} / \mathrm{m}^{2} \mathrm{~K}$. Przyjęta do obliczeń prędkość spawania była identyczna z tą zastosowaną podczas prób doświadczalnych spawania hybrydowego płyt i wynosiła $100 \mathrm{~cm} / \mathrm{min}$. Z uwagi na zastosowaną symetrię modelu powierzchnia znajdująca się w jej płaszczyźnie została wyizolowana cieplnie. Zastosowane w obliczeniach numerycznych właściwości materiałowe (gęstość, przewodność cieplna, ciepło właściwe) przyjęto w funkcji temperatury jak dla czystego żelaza na podstawie danych literaturowych [14].

\section{Wyniki obliczeń}

W wyniku przeprowadzonych obliczeń numerycznych na zbudowanym modelu dwóch płyt stalowych spawanych doczołowo metodą hybrydową plazma+GMA uzyskano rozkład pola temperatury w złączu w dowolnym jego przekroju oraz w dowolnej chwili czasu przemieszczającego się spawalniczego źródła ciepła. Na rysunku 5 przedstawiono wyniki symulacji rozkładu pola temperatury $\mathrm{w}$ analizowanym złączu spawanym w postaci kolejnych przekrojów poprzecznych w trakcie procesu spawania hybrydowego.

Kolor czerwony na rysunku 5 reprezentuje obszar, w którym temperatura przekracza $1500{ }^{\circ} \mathrm{C}$, a zatem można to przybliżyć do obszaru ciekłego jeziorka. Wyraźnie widać, że prawa część rysunku 5 obejmuje niemal całą grubość materiału, co może świadczyć o uzyskaniu pełnego przetopu w materiale. Z kolei po lewej stronie obszar roztopienia

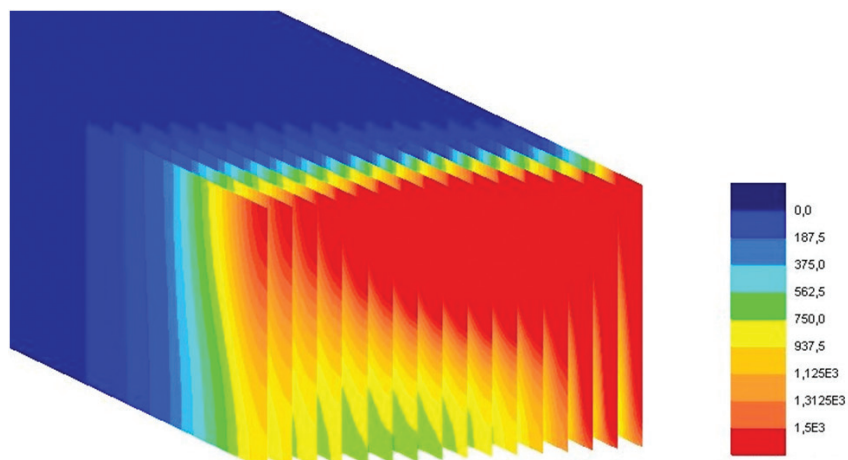

Rys. 5. Poszczególne przekroje poprzeczne pola temperatury $w$ trakcie spawania hybrydowego plazma+GMA

Fig. 5. Subsequent cross-sections of temperature field in plasma+GMA hybrid welded joint

staje się coraz płytszy. Całość obrazuje zastosowany model hybrydowy spawalniczego źródła ciepła, w którym na początku oddziałuje na materiał spawany skoncentrowany łuk plazmowy a zaraz za nim podąża klasyczny łuk elektryczny jak przy spawaniu metodą GMA. Oba łuki podążają równocześnie w pewnej niewielkiej odległości od siebie wynikającej z konstrukcji głowicy do spawania hybrydowego plazma+GMA.

W symulacji numerycznej pola temperatury podczas spawania uzyskanie kształtu spoiny w przekroju poprzecznym złącza jest możliwe dzięki nałożeniu na siebie kolejnych rozpatrywanych przekrojów. Wynika to z faktu, iż w określonej chwili czasu w każdym kolejnym przekroju rozkład pola temperatury jest inny. Dopiero ich zsumowanie pozwala uzyskać obraz (rys. 6), który można odnieść bezpośrednio do danych doświadczalnych otrzymanych po spawaniu. Pewnym niekorzystnym efektem sumowania rozkładów pola temperatury z wielu przekrojów złącza może być częściowe zaburzenie ciągłości izoterm, co widoczne jest na rysunku 6. Wyznaczony w ten sposób w analizie numerycznej rozkład pola temperatury można odnieść i porównać z obrazem mikrostruktury spawanego złącza. Otrzymany kształt pola temperatury z wyraźnie zaznaczonym obszarem, w którym przekroczona została temperatura topnienia wskazuje na kształt powstającej spoiny.

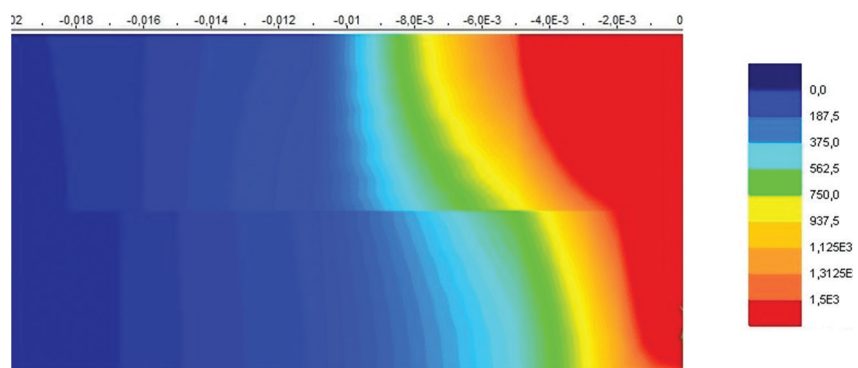

Rys. 6. Obliczony rozkład pola temperatury w przekroju poprzecznym złącza spawanego metodą hybrydową plazma+GMA

Fig. 6. Temperature field distribution calculated in a cross-section of plasma+GMA hybrid welded joint

Jest to, jak już wspomniano, jedna z pierwszych metod oceny dokładności zbudowanego modelu spawalniczego źródła ciepła, które ma decydujący wpływ na wielkość i rozkład pola temperatury $w$ spawanych materiałach. Przedstawione na rysunku 7 bezpośrednie porównanie struktury przekroju złącza spawanego z rozkładem temperatury w przekroju tego złącza, wyznaczonym dla parametrów źródła ciepła obliczonych na podstawie parametrów spawania analizowanych materiałów wskazuje, że zbudowany model hybrydowy plazma+GMA spawalniczego źródła ciepła w dość dobrym stopniu odzwierciedla kształt powstałej spoiny. 


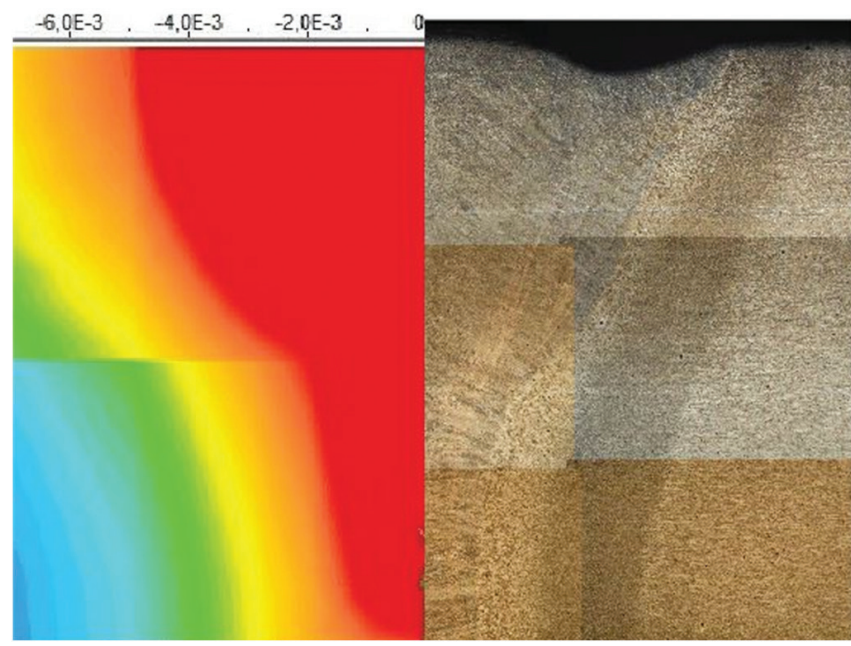

W jej dolnej części widoczny jest zawężony przekrój spoiny wynikający z oddziaływania jedynie skoncentrowanego strumienia łuku plazmowego na materiał, natomiast spawalniczy łuk elektryczny występujący w tej odmianie spawania hybrydowego, podąża za łukiem plazmowym i oddziałuje jedynie na górną część spoiny mając za zadanie prawidłowe wypełnienie spoiny oraz jej lica. Na obu porównywanych obrazach widać więc występowanie dwóch obszarów spoiny o różnej szerokości wynikającej z zastosowania źródeł ciepła o różnym stopniu koncentracji energii cieplnej.

Rys. 7. Porównanie kształtu spoin w przekroju poprzecznym dla badań numerycznych oraz doświadczalnych

Fig. 7. Comparison of the weld shape in a cross-section between calculated and experimental results

\section{Podsumowanie i wnioski}

Procesy spawania hybrydowego charakteryzują się jednoczesnym współdziałaniem dwóch źródeł ciepła o zazwyczaj odmiennej charakterystyce. W procesie modelowania pola temperatury $w$ tego typu procesach wymagane jest więc zastosowanie innego rodzaju modelu źródła ciepła niż w klasycznym spawaniu łukowym czy też metodami wiązkowymi. Najczęściej wymagane jest stworzenie nowego modelu spawalniczego źródła ciepła będącego w pewnym sensie złożeniem dwóch różnych źródeł ciepła biorących udział w procesie spawania. Model taki wymaga często indywidualnego podejścia w zależności od zastosowanego wariantu spawania hybrydowego oraz parametrów procesu.

W pracy przeprowadzono obliczenia numeryczne umożliwiające zobrazowanie pola temperatury w dowolnej chwili czasu podczas spawania hybrydowego w odmianie plazma+GMA, która nie jest jeszcze dość dobrze opisana od strony modelu hybrydowego źródła ciepła. Zaproponowany i zbudowany wstępny model takiego źródła oparto na połączeniu modelu Goldaka z modelem prostopadłościennym. Otrzymane wyniki rozkładu pola temperatury odniesiono do rzeczywistego kształtu spoiny otrzymanego podczas spawania hybrydowego analizowanych materiałów zachowując podobne parametry procesu. Wstępna zbieżność wyników obliczeń numerycznych z kształtem rzeczywistej spoiny daję podstawę do dalszych badań nad rozwojem zaproponowanego modelu hybrydowego źródła ciepła. Dla uzyskania większej zbieżności wyników obliczeń rozkładu pola temperatury z badaniami eksperymentalnymi powinny być zastosowane badania takie jak rejestracja pola temperatury kamerą termowizyjną czy też z wykorzystaniem termopar. Obliczenia numeryczne dają olbrzymie możliwości prowadzenia rozbudowanej analizy pola temperatury w procesie spawania, co nie jest możliwe do uzyskania na podstawie samego modelu fizycznego procesu.

Na podstawie przeprowadzonych badań i analiz można wyciągnąć następujące wnioski:

- Widoczna jest dość duża zgodność wyników porównując kształt spoiny w przekroju poprzecznym dla badań numerycznych oraz doświadczalnych. Zarówno zarys linii wtopienia, jak i wymiary spoiny są podobne. Świadczy to o poprawnych założeniach przyjętych do budowy modelu źródła ciepła podczas spawania hybrydowego plazma+GMA, który może być dalej rozwijany i stosowany w dalszych analizach pola temperatury.

- Pomimo tego, że zbudowany model źródła ciepła nie uwzględnia takich zjawisk zachodzących w ciekłym jeziorku jak np. oddziaływanie siły napięcia powierzchniowego czy ruchów ciekłego jeziorka, to może on być bardzo przydatny dla uzyskania poprawnego rozkładu temperatury w złączu spawanym, który z kolei odgrywa kluczową rolę w analizie odkształceń i stanu naprężeń spawalniczych.

\section{Praca finansowana ze środków na działalność statutową Zakładu Inżynierii Spajania Politechniki Warszawskiej}

\section{Literatura}

[1] Komanduri R., Hou, Z.B.: Thermal Analysis of the Arc Welding Process: Part I. General Solutions, Metallurgical and Materials Transactions B, Vol. 31B, pp. 1353-1370, 2000

[2] Kowalczyk P., Golański D., Chmielewski T., Włosiński W.: Analiza porównawcza rozkładu temperatury i naprężeń podczas uderzenia cząstki Ti w podłoże metalowe i ceramiczne podczas natryskiwania detonacyjnego, Przegląd Spawalnictwa 6, 2014, s.40-45.

[3] Golanski D.: Temperature distribution in a cylindrical Al203-steel joint during the vacuum brazing cycle, Journal of Materials Processing Technology, vol. 56 (1-4), pp. 945-954, 1996.

[4] Hudycz M., Chmielewski T., Golański D.: Analysis of Distribution of Temperature and StressesDuring the Friction Metallisation of AIN Ceramics with Titanium, Biuletyn Instytutu Spawalnictwa w Gliwicach, vol. 60, No. 5, pp. 63-67, 2016.
[5] Choa J.R., Leea B.Y., Moonb Y.H., Van Tynec C.J.: Investigation of residual stress and post weld heat treatment of multi-pass welds by finite element method and experiments, Journal of Materials Processing Technology, Vol. 155-156, pp. 1690-1695, 2004.

[6] Yi H-J, Kim J-Y, Yoon Y-H, Kang S-S: Investigations on welding residual stress and distortion in a cylinder assembly by means of a 3D finite element method and experiments, Journal of Mechanical Science and Technology, Vol. 25, Issue 12, pp. 3185-3193, 2011.

[7] Goldak J., Chakravarti A., Bibby M.: A new finite element model for welding heat sources, Metallurgical Transactions B, vol. 15, no. 2, pp. 299-305, 1984

[8] Rochalski D., Golański D., Chmielewski T.: Modele spawalniczych źródeł ciepła w analizie pola temperatury, Przegląd Spawalnictwa vol.89, No. 5/2017, s.109-116. 
[9] Shanmugam N. Siva, Buvanashekaran G., Sankaranarayanasamy K.: Some Studies on Temperature Distribution Modeling of Laser Butt WeIding of AISI 304 Stainless Steel Sheets, International Journal of Mechanical, Aerospace, Industrial, Mechatronic and Manufacturing Engineering Vol. 7, No. 7, 2013, pp. 1532-1541.

[10] Sun J., Liu X., Tong Y., Deng D.: A comparative study on welding temperature fields, residual stress distributions and deformations induced by laser beam welding and $\mathrm{CO}_{2}$ gas arc welding. Materials and Design, vol.63, 2014, pp. 519-530.

[11] Reutzel E.W., Kelly S.M., Martukanitz R.P., Bugarewicz M.M., Michaleris P. Laser-GMA Hybrid Welding: Process Monitoring and Thermal Modelling, in: S.A. David et al. (Eds.), Proceedings of the 7th International Conference on Trends in Welding Research, Callaway Gardens Resort, Pine Mountain, Georgia,USA, 2005, pp. 143-148.
[12] Katayama S., Naito Y., Uchiumi S., Mizutani M.: Laser-Arc Hybrid Welding, Solid State Phenomena Vol. 127, 2007, pp. 295-300.

[13] Szulc J., Chmielewski T., Pilat Z.: Zrobotyzowane spawanie hybrydowe Plazma+MAG stali S700 MC, Przegląd Spawalnictwa, vol. 88, Nr 1, s. 40-45.

[14] Goldsmith A., Waterman T.E., Hirchorn H.J.: Handbook of thermophysicalproperties of solid materials, New York, 1961. 